KATARZYNA MAJCHRZAK

Wydział Prawa Kanonicznego

Uniwersytetu Kardynała Stefana Wyszyńskiego w Warszawie

\title{
URLOPY WYPOCZYNKOWE W ŚWIETLE PRZEPISÓW PRAWA PRACY
}

Treść: Wstęp. - 1. Coroczny okres wypoczynku. - 2. Wymiar urlopu wypoczynkowego. - 3. Sposób i cel wykorzystania urlopu wypoczynkowego. - 4. Ekwiwalent pieniężny za niewykorzystany urlop. - 5. Urlop na żądanie. - 6. Urlop wypoczynkowy młodocianych pracowników. - Zakończenie.

\section{Wstęp}

Uprawnienia urlopowe zaliczamy do instytucji prawa do wypoczynku - wypoczynku corocznego. Zadaniem zasady prawa do wypoczynku jest poprawne określenie granicy pomiędzy czasem zawodowym a prywatnym. Zgodnie $\mathrm{z}$ art. 14 kodeksu pracy przepisy dotyczące urlopów wypoczynkowych, obok problematyki czasu pracy i dni wolnych od pracy, mają na celu zapewnienie pracownikom odpowiedniego okresu odpoczynku. Zagadnienia związane z urlopami odgrywają z punktu widzenia ochronnego bardzo znaczącą rolę. Dzieje się tak, ponieważ funkcją urlopu wypoczynkowego, jako corocznego, nieprzerwanego i płatnego zwolnienia od pracy, jest przede wszystkim regeneracja sił fizycznych i psychicznych pracownika ${ }^{1}$.

\footnotetext{
${ }^{1}$ T. Nycz, Ochronny charakter przepisów o czasie pracy - wybrane zagadnienia, Praca i Zabezpieczenie Społeczne nr 3/1999, s. 2 - 3.
} 


\section{Coroczny okres wypoczynku}

Istotą i celem urlopu wypoczynkowego jest zapewnienie pracownikowi wypoczynku dla regeneracji jego sił utraconych w trakcie wykonywania pracy w ciągu roku² ${ }^{2}$. Dlatego też, urlop wypoczynkowy jest jednym $z$ podstawowych świadczeń pracowniczych. Potwierdza to choćby fakt, iż zagadnienia dotyczące urlopów wypoczynkowych, zostały szczegółowo unormowane w dziale siódmym kodeksu pracy. Znajduje to również wyraz w wielu regułach określonych przepisami tegoż działu. Przykładowo warto wskazać, iż pracownik nie może zrzec się prawa do urlopu, urlop nie powinien być dzielony na części i zasadniczo powinno się wykorzystać przysługujący urlop w naturze ${ }^{3}$.

Od innych urlopów i zwolnień udzielanych pracownikom, jak na przykład wychowawczych czy macierzyńskich, urlop wypoczynkowy różni się zwłaszcza celem, jakiemu służy oraz tym, że przysługuje corocznie i jest płatny. Inne urlopy i zwolnienia od pracy mogą być udzielane tylko w określonych sytuacjach, $\mathrm{z}$ reguły na wniosek pracownika i nie zawsze są odpłatne ${ }^{4}$. Urlop wypoczynkowy to czas corocznego dłuższego odpoczynku, który stanowi psychofizjologiczną konieczność. Kiedy wzrasta nadmierne tempo i napięcie pracy, gdy przybiera ona jednostronny charakter, obciążający wciąż te same zespoły mięśni i ośrodki nerwowe, pojawia się wówczas poczucie monotonii. W konsekwencji powstaje kompleks objawów wyczerpania fizycznego i nerwowego, dlatego potrzebujemy wtedy wypoczynku ${ }^{5}$. Prawo do urlopu wypoczynkowego, jako jedno z podstawowych uprawnień pracownika, zostało zagwarantowane w Konstytucji RP oraz w kodeksie pracy ${ }^{6}$. Prawo wspólnotowe, które po przystąpieniu Polski do Unii Europejskiej, stało się integralną częścią prawa

\footnotetext{
${ }^{2}$ J. Hejno, Pracownicze urlopy wypoczynkowe, Warszawa 1990, s. 3.

${ }^{3}$ E. Wichrowska - Janikowska, Urlopy pracownicze, Warszawa 1994, s. 7.

${ }^{4}$ F. MaŁysz, Pracownicze urlopy wypoczynkowe, Warszawa 1987, s. 4.

${ }^{5}$ J. Danecki, Czas wolny. Mity i potrzeby, Warszawa 1967, s. 64, 136.

${ }^{6}$ K. Jaśkowski - E. ManiewsKa, Kodeks Pracy. Komentarz, Zakamycze 2003, s. 392.
} 
polskiego, na mocy przepisu art. 7 dyrektywy 2003/88/WE, również daje pracownikom uprawnienie do korzystania z płatnego, corocznego urlopu wypoczynkowego, w wymiarze, co najmniej 4 tygodni ${ }^{7}$.

O warunkach nabywania i zasadach korzystania z urlopów decydują przepisy krajowego prawa pracy. Płatne urlopy wypoczynkowe przysługują pracownikom, niezależnie od dni ustawowo wolnych od pracy. W europejskim prawie pracy obowiązuje zasada zgodnie, z którą długość urlopów pracowniczych liczymy w dniach roboczych. Dyrektywa zabrania zwolnienia się pracodawcy z obowiązku udzielenia urlopu wypoczynkowego w naturze przez zapłacenie ekwiwalentu pieniężnego za nie wykorzystany urlop. Wyjątkowo ekwiwalent można wypłacić, kiedy zaistnieje sytuacja, iż pracownik nie może urlopu wykorzystać, z powodu rozwiązania umowy o pracę ${ }^{8}$.

Prawo do urlopu, zgodnie z art. 152 kodeksu pracy oznacza, że pracownik może domagać się od zatrudniającego, udzielenia mu corocznego, płatnego i nieprzerwanego urlopu wypoczynkowego ${ }^{9}$. Celem urlopu jest wypoczynek pracownika, czyli ochrona jego zdrowia. Dzięki temu, prawo do urlopu ma charakter osobisty i nie może być przeniesione na inną osobę nawet za obustronną zgodą. Umowa między pracodawcą a pracownikiem na podstawie, której pracownik przeniósłby swoje prawo do urlopu na innego pracownika jest nieważna. Ustawodawca wyraźnie w art. $152 \$ 2$ kodeksu pracy, podkreślił, iż pracownik nie może zrzec się tego prawa. Zasada niezbywalności prawa do urlopu wypoczynkowego stanowi gwarancję rzeczywistego wykorzystania urlopu, a w rezultacie realizację celów

${ }^{7}$ M. Matey, Nowy ład pracy w Polsce i $w$ Europie, Warszawa 1997, s. 171; Por. L. FloREK, Dostosowanie polskiego prawa pracy do prawa unijnego ze szczególnym uwzględnieniem ostatniej nowelizacji Kodeksu pracy, Monitor Prawa Pracy nr 1/2004, s. 7.

${ }^{8}$ Por. A. M. Świątкowski, Europejskie prawo socjalne, tom II, Warszawa 1999, s. 215.

${ }^{9}$ W. Ćwiek, Wszystko o urlopach, Prawo Pracy. Dla Pracodawców i Pracowników z Zakresu Stosunku Pracy Zatrudnienia i Spraw Socjalnych nr 28/1999, s. 7; Zob. G. ZdZIENNICKA - KaCzocha, Urlopy wypoczynkowe od 1 stycznia 1997 r., Skierniewice 1997, s. 6. 
związanych z tym urlopem. Zatem głównym celem tego unormowania, jest zapewnienie pracownikowi zdrowia fizycznego i psychicznego, nawet wówczas, kiedy $\mathrm{z}$ jakichś względów chciałby on $\mathrm{z}$ tego zrezygnować. Niewątpliwie, gdyby istniała możliwość rezygnacji przez pracownika z przysługującego mu prawa do urlopu wypoczynkowego, zwłaszcza w dzisiejszej trudnej sytuacji ekonomicznej, pracodawcy mogliby wymuszać na pracownikach lub zachęcać ich do tej rezygnacji, w zamian oferując niewielkie dodatkowe wynagrodzenie. Początkowo działanie takie, dla pracownika w trudnej sytuacji finansowej, mogłoby wydawać się korzystne. Jednak w konsekwencji mogłoby doprowadzić do wymuszonego świadczenia pracy bez odpoczynku, a wkrótce nawet do niemożności wykonywania pracy przez pracownika ze względów zdrowotnych. W takiej sytuacji nie byłoby to już korzystne ani dla pracownika, ani dla pracodawcy, który wcześniej nadmiernie eksploatował zatrudnionych ${ }^{10}$. W związku z zakazem zrzekania się prawa do urlopu Sąd Najwyższy 7 lutego 1967 r. wydał wyrok zgodnie, z którym pracownik nie tylko w umowie o pracę, lecz także w czasie jej trwania nie może skutecznie zrzec się prawa do urlopu wypoczynkowego i to zarówno bieżącego, jak i zaległego, jeśli urlop może jeszcze wykorzystać. Nie ma natomiast w zasadzie przeszkód do uznania skuteczności zrzeczenia się przez pracownika ekwiwalentu pieniężnego za urlop, którego pracownik nie może już wykorzystać. Zrzeczenie takie należy ocenić według przepisów o czynnościach prawnych ${ }^{11}$.

Kodeksowa regulacja prawa do urlopu wypoczynkowego ma charakter powszechny. Dotyczy, zatem ogółu pracowników, bez względu na podstawę ich zatrudnienia. Może to być umowa o pracę, powołanie, wybór, mianowanie czy spółdzielcza umowa o pracę. Uprawnienie to nie przysługuje osobom wykonującym pracę na podstawie

\footnotetext{
${ }^{10}$ I. JARoszewsKa - IgnAtowska, Urlopy pracownicze, Warszawa 2003, s. 14-15.

${ }^{11}$ Wyrok Sądu Najwyższego z dnia 7 lutego 1967 r. I PR 53/67, OSP nr 12/1967, poz. 287, LEX 558190.
} 
umów cywilnoprawnych, na przykład umowy zlecenia lub umowy o dzieło ${ }^{12}$.

\section{Wymiar urlopu wypoczynkowego}

Zasada, iż pracownik ma prawo do corocznego urlopu wypoczynkowego oznacza, iż urlop powinien być zaplanowany i udzielony w roku kalendarzowym, w którym pracownik nabył do niego prawo. Wynika to przede wszystkim $\mathrm{z}$ konieczności spełnienia podstawowego celu urlopu, czyli zregenerowania sił zużytych w procesie pracy $^{13}$.

Ustawodawca w art. 153 kodeksu pracy określił zasady nabywania prawa do pierwszego urlopu wypoczynkowego. Pominięto obowiązującą przed 1 stycznia 2004 r. zasadę nabywania prawa do urlopu $\mathrm{z}$ upływem 6 miesięcy pracy w wymiarze połowy przysługującego urlopu. Natomiast pozostałą część urlopu można było wykorzystać dopiero z upływem roku od rozpoczęcia pierwszej pracy. W myśl obowiązujących przepisów, pracownik podejmujący pracę po raz pierwszy nabywa prawo do urlopu z upływem każdego miesiąca pracy, w wymiarze 1/12 wymiaru przysługującego mu po przepracowaniu roku. Prawo do kolejnych urlopów, pracownik nabywa w każdym następnym roku kalendarzowym ${ }^{14}$. Warto pamiętać, że nabycie prawa do pierwszego jak i kolejnego urlopu, nie jest uzależnione od faktycznego wykonywania pracy, ale od trwania stosunku pracy. Prawo do urlopu wypoczynkowego można, bowiem uzyskać tylko w czasie trwania stosunku pracy. Oznacza to, że sama praca nie musi być faktycznie wykonywana. Dlatego pracownik, który z powodu choroby nie był obecny w pracy w dniu upływu wymaganego okresu zatrudnienia, również nabywa prawo do urlopu. Pracownik, który w dniu 1 stycznia nie

\footnotetext{
${ }^{12}$ A. Martuszewicz, Urlopy pracownicze, Prawo Pracy - Prawo Przedsiębiorcy nr 3/2000, s. 2.

${ }^{13}$ E. Wichrowska - Janikowska, Plan urlopów, Praca i Zabezpieczenie Społeczne nr 1/1999, s. 30.

${ }^{14}$ J. StrusińsKa - Żunowska, Wszystko o urlopach wypoczynkowych, Prawo Pracy $\mathrm{nr}$ 6/2003, s. 4; Zob. Z. SAlwa, Nabycie prawa do urlopu wypoczynkowego po nowelizacji Kodeksu pracy, Praca i Zabezpieczenie Społeczne nr 4/1996, s. 34-41.
} 
przystępuje do pracy z powodu konieczności sprawowania opieki nad chorym dzieckiem, ale pozostający w zatrudnieniu, nabywa prawo do kolejnego urlopu ${ }^{15}$. Podobna sytuacja zachodzi, kiedy pracownik korzysta ze świadczenia rehabilitacyjnego. Sąd Najwyższy 4 kwietnia 1995 r. podjął uchwałę, zgodnie z którą pracownik nabywa prawo do kolejnego urlopu wypoczynkowego z dniem 1 stycznia danego roku, mimo że pozostając w stosunku pracy nie przepracował w tym roku kalendarzowym ani jednego dnia w związku z pobieraniem świadczenia rehabilitacyjnego ${ }^{16}$.

Wymiar urlopu wypoczynkowego dla pracowników zatrudnionych w pełnym wymiarze czasu pracy, na podstawie art. 154 kodeksu pracy, wynosi 20 lub 26 dni. Jest to uzależnione od okresu zatrudnienia pracownika. Jeżeli był on zatrudniony krócej niż 10 lat, należy mu się 20 dni urlopu. Prawo do 26 dni urlopu przysługuje pracownikowi, który jest zatrudniony, co najmniej 10 lat. Nowelizacja prawa urlopowego obowiązująca od 1 stycznia 2004 r. zmieniła wymiar urlopu pracownika zatrudnionego w niepełnym wymiarze czasu pracy. Zgodnie z art. $154 \$ 2$ wymiar urlopu ustala się proporcjonalnie do wymiaru czasu pracy pracownika. Jeśli na skutek takiego obliczenia powstanie wynik ułamkowy, wówczas niepełny dzień urlopu zaokrągla się w górę do pełnego dnia. Jednak nigdy wymiar urlopu nie może przekroczyć 20 lub 26 dni w zależności od okresu zatrudnienia ${ }^{17}$. Uprawnienia urlopowe zależą od ogólnego stażu pracy, czyli łącznego pozostawania w stosunkach pracy u różnych pracodawców. Dlatego do okresu zatrudnienia od którego zależy wymiar urlopu wlicza się nie tylko czas trwania aktualnego zatrudnienia, ale także inne stosunki pracy, które już się zakończyły albo nadal trwają. Staż urlopowy w przypadku zakończonych okresów zatrudnienia ustala się na podstawie świadectw pracy. Należy mieć na uwadze fakt, że

\footnotetext{
${ }^{15}$ A. Gwarek, M. Skibicka - Ghaley, Urlopy pracownicze, Warszawa 1999, s. 16.

${ }^{16}$ Uchwała Sądu Najwyższego z dnia 4 kwietnia 1995 r. I PZP 10/95, OSNAP nr 18/1995, poz. 228.

${ }^{17}$ Por. E. Chmielek - Łubińska, Urlop wypoczynkowy po nowelizacji, Praca i Zabezpieczenie Społeczne nr 1/2004, s. 22-23.
} 
przyczyna wygaśnięcia lub rozwiązania stosunku pracy nie ma znaczenia przy obliczaniu okresu zatrudnienia od którego zależy wymiar urlopu wypoczynkowego. Wpływ na wymiar urlopu ma również wykształcenie pracownika. Ustawodawca bowiem wprowadził zasadę wliczania okresów nauki do stażu urlopowego. Uwzględnia się jednak tylko zakończone okresy pobierania nauki, potwierdzone zaświadczeniem lub dyplomem. Wymiar okresów wliczanych zależy od rodzaju ukończonej szkoły. W art. 155 kodeksu pracy ustawodawca wskazał konkretnie ile można wliczyć do stażu urlopowego z tytułu ukończenia określonej szkoły. Szczególna sytuacja może mieć miejsce, gdy pracownik ukończył szkołę jednocześnie pracując. Wówczas okresy pobierania nauki i pozostawania w stosunku pracy nie sumują się, a do stażu urlopowego wlicza się okres korzystniejszy dla pracownika (albo okres nauki, albo okres pozostawania w stosunku pracy).

Wymiar urlopu określony w art. 154 kodeksu pracy ma charakter minimalny i obowiązuje we wszystkich przypadkach, w których przepisy szczególne nie przewidują wyższego jego wymiaru dla określonych pracowników. Prawo do urlopu wypoczynkowego w wyższym wymiarze podstawowym albo prawo do dodatkowego urlopu wypoczynkowego może być gwarantowane przez układy zbiorowe pracy, jak również może wynikać z postanowień indywidualnej umowy o pracę ${ }^{18}$. Przykładowo można wskazać, iż na podstawie unormowań ustawowych prawo do wyższego wymiaru urlopu przysługuje: prokuratorom, na podstawie ustawy z dnia 28 stycznia 2016 r. Prawo o prokuraturze (Dz. U. z 2016 r., poz. 177), jak również nauczycielom na podstawie regulacji prawnej zawartej w przepisach rozdziału 7 ustawy z dnia 26 stycznia 1982 r. Karta Nauczyciela (Dz. U. z 2014 r., poz. 191, z późn. zm.).

Bez wątpienia, każdy pracownik ma prawo do corocznego, nieprzerwanego, płatnego urlopu wypoczynkowego. Nie ulega jednak wątpliwości, że korzystanie $\mathrm{z}$ tego prawa dotyka spraw związanych z funkcjonowaniem zakładu pracy i jego organizacją, dlatego art. 163 $\$ 1$ kodeksu pracy stanowi o tym, że urlopy powinny być udzielane

\footnotetext{
${ }^{18}$ J. Herbert, Urlopy pracownicze, Bydgoszcz 1997, s. 19-20.
} 
zgodnie z planem urlopów, który z kolei powinien być tak ustalony, aby jednocześnie uwzględniając wnioski pracowników co do czasu urlopu, zapewniony był normalny tok pracy. Dlatego trafny jest pogląd, że pracownik nie może korzystać z przysługującego mu prawa w dowolnym czasie, bez zgody pracodawcy. W pojęciu „udzielenie urlopu” mieści się, bowiem element decyzji, przyzwolenia pracodawcy na urlop. Gdy pracodawca nie jest obowiązany do ustalenia planu urlopów (sytuacja taka zachodzi gdy nie działa u niego zakładowa organizacja związkowa lub gdy działająca organizacja związkowa wyrazi zgodę na nieustalanie tego planu) wówczas pracodawca ustala termin urlopu po porozumieniu z pracownikiem. Orzecznictwo Sądu Najwyższego wskazuje, że zwrot „po porozumieniu” jest na ogół rozumiany jako wymóg uzyskania zgody. Ustalenie planu urlopów następuje przy spełnieniu dwóch warunków, po pierwsze musi być złożony wniosek przez pracownika a po drugie trzeba mieć na uwadze, że zakład pracy powinien funkcjonować normalnie w sposób niezakłócony. Przesłanki te są równoważne, dlatego można nie uwzględnić wniosku pracownika, jeżeli koliduje to $\mathrm{z}$ ważnym interesem pracodawcy. Warto w tym miejscu wspomnieć o wyjątku od zasady wyrażonej w art. $163 \$ 1$ kodeksu pracy, a mianowicie o prawnym uprzywilejowaniu pracownicy. W myśl przepisu art. $163 \$ 3$ na wniosek pracownicy pracodawca udziela jej urlopu wypoczynkowego bezpośrednio po urlopie macierzyńskim. Sąd Najwyższy w wyroku z dnia 20 sierpnia 2001 r. potwierdził, że zgodnie z ogólną zasadą pracodawca nie jest związany wnioskiem pracownika zawierającym propozycję terminu udzielenia urlopu, ale jest jednak związany takim wnioskiem, gdy pochodzi on od pracownicy, która urodziła lub ma urodzić dziecko i w związku z tym chciałaby przedłużyć czas sprawowania nad nim pełnej, osobistej opieki ${ }^{19}$.

\footnotetext{
${ }^{19}$ Wyrok Sądu Najwyższego z dnia 20 sierpnia 2001 r., I PKN 590/00, OSNP nr 14/2003, poz. 336, LEX 79000.
} 


\section{Sposób i cel wykorzystania urlopu wypoczynkowego}

Anna Dubowik słusznie zwróciła uwagę, że cel instytucji urlopu wypoczynkowego, jakim jest regeneracja sił pracownika, nie może być utożsamiana z obowiązkiem pracownika spędzenia urlopu wypoczynkowego w sposób zgodny z przeznaczeniem tej instytucji. Ważne jest jedynie, aby pracodawca udzielił pracownikowi urlopu w naturze zgodnie z obowiązującymi przepisami. Pracownik w czasie urlopu może wykonywać pracę zarobkową i nie jest to zabronione. Dopóki pracownik nie dopuści się zachowań, które mogłyby być uznane za naruszenie obowiązków pracowniczych wynikających z przepisów prawa pracy, dopóty sposób spędzania urlopu jest okolicznością obojętną z punktu widzenia prawa pracy. W czasie urlopu wypoczynkowego może, bowiem dojść do naruszenia przez pracownika obowiązków pracowniczych niezwiązanych bezpośrednio z obowiązkiem wykonywania pracy, jak na przykład obowiązek powstrzymania się od prowadzenia działalności konkurencyjnej ${ }^{20}$.

Urlop wypoczynkowy poprzez właściwe wykorzystanie czasu wolnego, ma zapewnić regenerację sił potrzebnych do dalszej pracy. Dlatego powinien on być wykorzystany w całości i w sposób nieprzerwany ${ }^{21}$. Ustawodawca dopuszcza jednak możliwość podzielenia urlopu na części. Sytuacja ta może zaistnieć tylko na wniosek pracownika. Pracodawca z własnej inicjatywy, nie może podzielić urlopu pracownika na części. W związku z tym, iż celem urlopu wypoczynkowego jest regeneracja sił pracownika ustawodawca, w art. 162 kodeksu pracy zastrzegł, że co najmniej jedna część urlopu powinna obejmować nie mniej niż 14 kolejnych dni kalendarzowych ${ }^{22}$. Gwarancją nieprzerywalności tego zwolnienia jest także ograniczenie możliwości odwołania z urlopu. Co do zasady urlop wypoczynkowy

\footnotetext{
${ }^{20}$ A. Duвоwiк, Zasada udzielania urlopu wypoczynkowego w naturze i plan urlopów, Praca i Zabezpieczenie Społeczne nr 5/2003, s. 33.

${ }^{21}$ J. Strusińska - Żukowska, Kodeks pracy po zmianach od 1 stycznia 2003 r., Prawo Pracy nr 12/2002, s. 10; Por. M. Piekarski, Pracownicze urlopy wypoczynkowe, Palestra nr 9/1969, s. 31.

22 J. StrusińsKa - Żukowska, Urlopy wypoczynkowe, Warszawa 1997, s. 24-25.
} 
nie powinien być zakłócany. Wyjątkowo na podstawie art. 167 kodeksu pracy, pracodawca może odwołać pracownika z urlopu. Jednak sytuacja ta może zaistnieć, tylko wtedy, gdy obecności pracownika w zakładzie wymagają okoliczności nieprzewidziane w chwili rozpoczęcia urlopu. Pracodawca ma obowiązek pokryć koszty, które pracownik poniósł, w bezpośrednim związku z odwołaniem go z urlopu. Przykładowo mogą to być koszty przejazdu do miejsca spędzenia urlopu i z powrotem czy koszty zakwaterowania w domach wczasowych ${ }^{23}$.

Za czas urlopu pracownikowi przysługuje wynagrodzenie, jakie by otrzymywał, gdyby w tym czasie pracował i dotyczy to stałych składników wynagrodzenia. Zmienne składniki wynagrodzenia, jak mówi art. 172 kodeksu pracy, mogą być obliczone na podstawie przeciętnego wynagrodzenia z okresu 3 miesięcy poprzedzających miesiąc rozpoczęcia urlopu. Okres ten może zostać przedłużony do 12 miesięcy, ale tylko w przypadkach znacznego wahania wysokości wynagrodzenia ${ }^{24}$.

\section{Ekwiwalent pieniężny za niewykorzystany urlop}

Urlop wypoczynkowy to uprawnienie, które winno być realizowane w naturalnej postaci, czyli korzystanie przez pracownika z czasu wolnego od pracy, ponieważ tylko w tej formie spełnia swój priorytetowy cel. Przekształcenie tej postaci urlopu w formę zastępczą, czyli ekwiwalent pieniężny, jest dopuszczalne tylko w sytuacji, gdy nie można z przyczyn obiektywnych skorzystać z urlopu w naturze. Możliwość skorzystania z ekwiwalentu pieniężnego zachodzi w ściśle

\footnotetext{
${ }^{23}$ I. Boruta, Urlopy wypoczynkowe po zmianie Kodeksu pracy, Warszawa 1997, s. 54 .

${ }^{24}$ M. Barzycka - Banaszczy , Prawo pracy, Warszawa 1996, s. 102; Zob. J. RoMAŃCZUK, Urlopy wypoczynkowe po nowelizacji przepisów, Kontrola Państwowa nr 6/1997, s. 64-65. Szczegółowe zasady obliczania wynagrodzenia za urlop określa rozporządzenie Ministra Pracy i Polityki Socjalnej z dnia 8 stycznia 1997 r. w sprawie szczegółowych zasad udzielania urlopu wypoczynkowego, ustalania i wypłacania wynagrodzenia za czas urlopu oraz ekwiwalentu pieniężnego za urlop (Dz. U. Nr 2, poz. 14, z późn. zm.).
} 
określonych przypadkach, wymienionych w art. 171 kodeksu pracy, chodzi tu o sytuacje związane z rozwiązaniem lub wygaśnięciem stosunku pracy ${ }^{25}$. Stąd niewątpliwie czasowa nieobecność pracownika w pracy w związku z odbywaniem czynnej służby wojskowej lub jej form zastępczych nie upoważnia już pracodawcy do wypłacenia pracownikowi ekwiwalentu pieniężnego za urlop wypoczynkowy niewykorzystany do dnia powołania pracownika do odbycia takiej służby. Warto podkreślić, że prawo do ekwiwalentu pieniężnego powstaje $\mathrm{w}$ dniu rozwiązania lub wygaśnięcia stosunku pracy i jest niezależne od trybu rozwiązania stosunku pracy, jak też od przyczyn jego wygaśnięcia.

Ekwiwalent za niewykorzystany urlop nie ma charakteru odszkodowawczego, gdyż podstawą prawa do świadczenia nie jest wyrządzenie szkody, lecz inne zdarzenie. Jest to świadczenie wyjątkowe, ponieważ w myśl zasady prawa do wypoczynku obowiązuje reguła świadczenia urlopu w naturze ${ }^{26}$. Prawo do urlopu w naturze jest ściśle związane $\mathrm{z}$ osobą pracownika, dlatego $\mathrm{w}$ razie jego śmierci prawo to wygasa. Zaś prawo do ekwiwalentu pieniężnego za niewykorzystany urlop wypoczynkowy, przechodzi po śmierci pracownika na osoby uprawnione tj. małżonka i inne osoby spełniające warunki wymagane do uzyskania renty rodzinnej ${ }^{27}$.

Z pewnością obowiązek wypłacenia ekwiwalentu pieniężnego obciąża pracodawcę, u którego zostało nabyte prawo do urlopu wypoczynkowego i nie mogło być zrealizowane w naturze z powodu rozwiązania lub wygaśnięcia stosunku pracy. Natomiast samo roszczenie o ekwiwalent pieniężny za niewykorzystany urlop - bez względu

${ }^{25}$ M. ŁAJесzко, Urlop wypoczynkowy pracownika, Warszawa 1998, s. 15; Zob. E. WichrowsKa - JaNikowsKa, Wynagrodzenia za urlop i ekwiwalent pieniężny, Warszawa 1994, s. 74-87.

${ }^{26}$ J. JońcZyk, Prawo pracy, op. cit., s. 377; Zob. J. STRusińsKa - Żukowska, Kodeks pracy po zmianach od 29 listopada 2002 r., Prawo Pracy nr 11/2002, s. 13.

${ }^{27}$ J. Strusińska - Żukowska, Urlopy wypoczynkowe, Prawo Pracy nr 6/2002, s. 3. Warunki i tryb udzielania renty rodzinnej wynikają z przepisów ustawy z dnia 17 grudnia 1998 r. o emeryturach i rentach z Funduszu Ubezpieczeń Społecznych (Dz. U. z 2015 r., poz. 748 z późn. zm.). 
na to, czy chodzi o urlop bieżący czy zaległy - staje się wymagalne w dacie rozwiązania stosunku pracy.

Powinność wypłaty należnego ekwiwalentu pieniężnego nie jest uzależniona od rodzaju umowy o pracę ani od długości trwania zatrudnienia. Dlatego nawet po rozwiązaniu lub wygaśnięciu krótkotrwałej umowy o pracę na okres próbny lub na czas określony pracodawca zobowiązany jest wypłacić ekwiwalent za nabyty $\mathrm{w}$ trakcie tego zatrudnienia, a niewykorzystany urlop wypoczynkowy. Ustawodawca przewidział jeden wyjątek od powyższej reguły. Mianowicie w myśl przepisu art. $171 \$ 3$ kodeksu pracy, jeśli po rozwiązaniu lub wygaśnięciu umowy o pracę zatrudnienie z tym samym pracownikiem jest kontynuowane na podstawie kolejnej, bezpośrednio następującej umowy o pracę, to pracodawca ten może nie wypłacać ekwiwalentu, pod warunkiem że zawrze z pracownikiem porozumienie w sprawie wykorzystania urlopu w naturze w czasie pozostawania w kolejnym stosunku pracy.

Zasady ustalania wysokości ekwiwalentu za urlop są takie same jak w przypadku wynagrodzenia urlopowego. Przy obliczaniu ekwiwalentu pieniężnego za niewykorzystany urlop wypoczynkowy istotne znacznie mają dwa elementy. Po pierwsze obliczenie przeciętnego miesięcznego wynagrodzenia stanowiącego podstawę do obliczenia ekwiwalentu, a po drugie określenie współczynnika służącego do obliczania ekwiwalentu za 1 dzień urlopu ${ }^{28}$. Sąd Najwyższy w uchwale

\footnotetext{
${ }^{28}$ Najłatwiejsze jest obliczenie ekwiwalentu pieniężnego należnego pracownikowi, który otrzymuje miesięczne wynagrodzenie w stałej wysokości. Podstawę do obliczenia ekwiwalentu stanowi wynagrodzenie należne w miesiącu, w którym pracownik nabył prawo do ekwiwalentu. Dzieląc to wynagrodzenie przez współczynnik, uzyskujemy ekwiwalent za jeden dzień urlopu, a następnie po podzieleniu przez 8 - ekwiwalent za 1 godzinę urlopu. Z kolei mnożąc ekwiwalent za jedną godzinę urlopu przez liczbę godzin niewykorzystanego przez pracownika urlopu, otrzymujemy łączną kwotę należnego pracownikowi ekwiwalentu za niewykorzystany urlop.

W przypadku zmiennych składników wynagrodzenia podstawę do wyliczenia ekwiwalentu będzie stanowiło przeciętne miesięczne wynagrodzenie obliczone na podstawie tych składników.
} 
z dnia 20 sierpnia 1997 r. stwierdził, że w przypadku rozwiązania stosunku pracy i niewykorzystania $z$ tego powodu urlopu wypoczynkowego nabytego w pełnym wymiarze pracownikowi przysługuje od dotychczasowego pracodawcy ekwiwalent pieniężny odpowiadający urlopowi w wymiarze proporcjonalnym do okresu przepracowanego $\mathrm{u}$ tego pracodawcy w roku, w którym rozwiązano stosunek pracy, także w sytuacji gdy nastąpiło to $\mathrm{w}$ związku z nabyciem przez pracownika uprawnień emerytalnych ${ }^{29}$.

\section{Urlop na żądanie}

W związku z urlopem wypoczynkowym, warto zwrócić uwagę na instytucję urlopu na żądanie pracownika, która została uregulowana w art. $167^{2}$ kodeksu pracy. Urlop ten wynosi 4 dni w roku kalendarzowym. Nie jest to urlop dodatkowy, gdyż przysługuje w ramach obowiązkowego dla pracownika wymiaru urlopu wypoczynkowego. Istotą jego jest to, że pracownik zgłasza pracodawcy żądanie udzielenia mu urlopu $\mathrm{w}$ terminie przez siebie wskazanym, jednak żądanie to nie może być zgłoszone później niż w dniu rozpoczęcia urlopu. Przepis stwarza problem interpretacyjny w zakresie rozstrzygnięcia kwestii czy pracownik może rozpocząć omawiany urlop bez oświadczenia pracodawcy, że udziela mu urlopu. Orzecznictwo w omawianym zakresie nie jest jednolite. Wydaje się jednak że przeważa rygorystyczny pogląd, że pracownik nie może rozpocząć urlopu na żądanie bez udzielenia go przez pracodawcę. Sad Najwyższy w wyroku z dnia 16 września 2008 r., II PK 26/08, stwierdził, że rozpoczęcie urlopu na żądanie przed udzieleniem go przez pracodawcę może być uznane za nieusprawiedliwioną nieobecność w pracy, będącą ciężkim naruszeniem podstawowych obowiązków pracowniczych w rozumieniu art. $52 \S 1$ pkt 1 kodeksu pracy ${ }^{30}$. Pogląd, iż urlop na żądanie nie wymaga decyzji pracodawcy o jego udzieleniu opiera

\footnotetext{
${ }^{29}$ Uchwała Sądu Najwyższego z dnia 20 sierpnia 1997 r., III ZP 26/97, OSNP nr 5/1998, poz. 145, LEX 31534.

${ }^{30}$ Wyrok Sądu Najwyższego z dnia 16 września 2008 r., II PK 26/08, OSNP nr 3-4/2010, poz. 36, LEX 558190.
} 
się na wykładni językowej. Jednak należy pamiętać o funkcji organizatorskiej prawa pracy i konieczności zapewnienia prawidłowego procesu organizacji pracy. Stąd słuszne są argumenty przemawiające za tym, że pracownik nie może „sobie samemu” udzielić urlopu na żądanie. Nieobecność pracownika nie powinna szkodzić interesom zakładu pracy (pracodawcy) ${ }^{31}$.

Urlop na żądanie stanowi część urlopu wypoczynkowego, dlatego powinien on być przeznaczony na wypoczynek. Jednak - jak zauważyła Ewa Chmielek-Łubińska - polskie prawo urlopowe nie przewiduje żadnych mechanizmów prawnych, które miałyby za zadanie sprawdzić czy pracownik przeznacza urlop na wypoczynek, czy też nie. Nie można wykluczać, że pracownik owe cztery dni przeznaczy na wypoczynek, jednak nie można też wykluczyć, że będzie to inny cel zwłaszcza, gdy pracownik korzysta z każdego dnia urlopu oddzielnie ${ }^{32}$.

Ustanowienie obowiązku pracodawcy udzielenia pracownikowi na jego żądanie części urlopu wypoczynkowego ma na celu uwzględnienie nadzwyczajnych sytuacji, które powodują, iż pracownik w danym terminie nie może świadczyć pracy. Mając na uwadze socjalny cel urlopu wypoczynkowego, należy uznać, iż owe sytuacje powinny mieścić się w tym celu. Ustawodawca nie ustanowił jednak obowiązku uzasadniania przez pracownika jego żądania o udzielenie mu urlopu, dlatego pracodawca pozbawiony jest możliwości weryfikacji tegoż założenia. Dzięki temu, w praktyce urlop na żądanie pracownika będzie udzielany zarówno wtedy, gdy wskutek przemęczenia będzie on potrzebował krótkiego wypoczynku, jak również dla załatwienia spraw rodzinnych lub osobistych ${ }^{33}$.

\footnotetext{
${ }^{31}$ Wyrok Sądu Najwyższego z dnia 26 stycznia 2005 r., II PK 197/04, OSNP nr 17/2005, poz. 271; Wyrok Sądu Najwyższego z dnia 28 października 2009 r., II PK 123/09, OSNP nr 11-12/2011, poz. 148.

${ }^{32}$ E. ChMielek - Łubińska, Urlop na żądanie pracownika, Praca i Zabezpieczenie Społeczne nr 3/2003, s. 26; Zob. T. Nycz, Nowe zasady urlopowe, s. 70-71.

${ }^{33}$ K. RĄCzKa, Urlopy wypoczynkowe po zmianach, Praca i Zabezpieczenie Społeczne nr 10/2002, s. 25.
} 


\section{Urlop wypoczynkowy młodocianych pracowników}

Odmienność regulacji w zakresie prawa do urlopu, stanowi element ochrony zdrowia młodocianych. Uprawnienia urlopowe młodocianych zostały ukształtowane korzystniej niż pracowników dorosłych. Jest to wynikiem konieczności zapewnienia ochrony zdrowia młodocianych i umożliwienia im regeneracji sił po stosunkowo krótkim okresie pracy, a także umożliwienia stopniowego przystosowania się do obowiązków związanych z wykonywaniem pracy zawodowej ${ }^{34}$. Młodociany ma zwiększony wymiar urlopu i krótszy okres wyczekiwania na urlop. W myśl art. 205 kodeksu pracy, młodociany, który podejmuje pracę po raz pierwszy, nabywa prawo do pierwszego urlopu $\mathrm{z}$ upływem 6 miesięcy w wymiarze 12 dni roboczych, zaś z upływem roku pracy w wymiarze 26 dni roboczych. Jednakże w roku kalendarzowym, w którym kończy on 18 lat, ma prawo do urlopu w zmniejszonym wymiarze, a mianowicie $20 \mathrm{dni}$ (jeśli prawo to uzyskał przed ukończeniem 18 lat). Dodać należy, iż wobec pracownika młodocianego uczęszczającego do szkoły pracodawca jest zobowiązany do udzielenia urlopu w okresie ferii szkolnych. Ustawodawca wprowadził, to zalecenie mając przede wszystkim na uwadze podstawowy cel urlopu wypoczynkowego jakim jest odpoczynek, a byłoby to wykluczone gdyby młodociany w czasie ferii świadczył pracę. Podobnie młodociany, który korzystałby z urlopu wypoczynkowego odbywając równolegle zajęcia w szkole nie korzystałby z tego urlopu zgodnie $\mathrm{z}$ jego przeznaczeniem jakim jest wypoczynek. Ponadto, jeżeli młodociany (uczeń szkoły dla pracujących) wystąpi z wnioskiem o udzielenie mu w okresie ferii szkolnych urlopu bezpłatnego, pracodawca jest zobowiązany udzielić takiego urlopu pod warunkiem, że łącznie z urlopem wypoczynkowym, urlop nie będzie dłuższy niż 2 miesiące. Okres urlopu bezpłatnego wlicza się do okresu pracy, od którego zależą uprawnienia pracownicze ${ }^{35}$. Niewątpliwie jest to rozwiązanie korzystniejsze niż przepisy art. $174 \$ 2$ kodeksu pracy dotyczące ogółu zatrudnionych, wyłączające okresy

\footnotetext{
${ }^{34}$ T. Zieliński, Kodeks Pracy. Komentarz, Warszawa 2003, s. 1000.

${ }^{35}$ M. BARzycka - BAnAszczy , Prawo pracy, Warszawa 2004, s. 291.
} 
urlopu bezpłatnego ze stażu pracy, od którego zależą uprawnienia pracownicze. Zdecydowanie takie szczególne uregulowanie wymiaru urlopu dla pracowników młodocianych ma na celu uwzględnienie ich potrzeb wynikających z wieku, w którym organizmy młodych pracowników wymagają dłuższego odpoczynku aby w pełni zregenerować siły.

\section{Zakończenie}

Przepisy prawa pracy starają się zachować odpowiednią równowagę między pracą a wypoczynkiem. Prawo do urlopu wypoczynkowego należy rozumieć jako przysługujące pracownikowi uprawnienie do przerwy w świadczeniu pracy. Pracownik ma zapewnione codzienne, cotygodniowe oraz coroczne okresy wypoczynku, dzięki którym może zregenerować siły i efektywnie wykonywać ciążące na nim obowiązki pracownicze.

Głównym atrybutem urlopu wypoczynkowego jest odpoczynek, mający na celu ochronę zdrowia fizycznego i psychicznego pracownika. Najważniejsze cechy urlopu wypoczynkowego wskazane wyraźnie w art. 152 kodeksu pracy przewidują, że powinien to być urlop coroczny, nieprzerwany i płatny.

Prawo do wypoczynku stanowi jedną z podstawowych zasad prawa pracy, a dobrem chronionym jest życie i zdrowie pracownika. Dlatego prawidłowe udzielenie urlopu wypoczynkowego należy traktować jako jeden z obowiązków pracodawcy. Należy pamiętać, że termin urlopów ustala się w planie urlopów lub w trybie indywidualnym po porozumieniu z pracownikiem. Przy czym pracownik powinien także mieć na uwadze potrzeby pracodawcy i ustalać termin urlopu w taki sposób aby nie zagrażało to płynności w funkcjonowaniu zakładu pracy.

Prawo do urlopu wypoczynkowego przedawnia się z upływem 3 lat. Zasadniczo bieg terminu przedawnienia rozpoczyna się z końcem roku kalendarzowego, w którym pracownik nabył prawo do urlopu wypoczynkowego. 


\section{Annual leave pursuant to the provisions of the labour code}

The article discusses the issues associated with annual leave pursuant the provisions of the labour law. The main purpose of an annual leave is to provide an employee with the opportunity to rest so she or he can fully regenerate physical and mental strength and efficiently perform the prescribed duties. The annual leave mechanism features primarily a protective function. An employee is entitled to annual leave every year, the leave is fully paid and it cannot be waived.

Annual leave is a privilege, which, given its purpose, should be provided in its natural form, in other words the employee should use the time off from work he or she is entitled to. However, in situations where the employee cannot utilise his or her annual leave in nature, he or she is entitled to cash equivalent.

Every employee is entitled to annual leave, that is why it should utilised in the calendar year in which this entitlement arises. Without doubt the use of this entitlement affects the organisation of the workplace and may often interfere with the normal course of work, and for that reason the legislator has introduced annual leave planning.

Juvenile employees enjoy annual leave entitlement which is more favourable than in case of adult employees. Reasons for such solution include their age and young organism that requires more time for rejuvenation as well as the opportunity to gradually adapt to their professional duties.

SŁOWA KLUCzOWE: urlop wypoczynkowy, plan urlopów, praca, odpoczynek

KeYwORDs: annual leave pursuant, plan of holidays, work, rest

\section{Nota o Autorze:}

DR KATARZYNA MAJCHRZAK - pracownik naukowo-dydaktyczny na Wydziale Prawa Kanonicznego Uniwersytetu Kardynała Stefana Wyszyńskiego w Warszawie, adiunkt w Katedrze Prawa Polskiego, radca prawny. 